pulmonary artery smooth muscle cells [1]. Most mutations of the BMPR2 gene lead to haploinsufficiency and the penetrance is highly variable. It has been suggested that a "second hit" is required to precipitate the phenotype and could cause further deregulation of BMPR2/Smad signalling, leading to PAH [9, 10]. Although the significance of gremlin levels in PAH has yet to be determined, in a mutation carrier developing IPF, hypoxia or increased gremlin levels may account for a second insult, leading to the manifestation of PAH.

0 @ERSpublications

Concurrent pulmonary hypertension and pulmonary fibrosis in a bone morphogenetic protein receptor type 2 mutation carrier http://ow.ly/qeG2Z

Aniek J. Raamsteeboers, Harm Jan Bogaard and Anton Vonk Noordegraaf

Dept of Pulmonary Medicine and Institute for Cardiovascular Medicine, VU University Medical Center, Amsterdam, The Netherlands.

Correspondence: A. Vonk Noordegraaf, Dept of Pulmonary Medicine, VU University Medical Center, De Boelelaan 1117, 1081 HV Amsterdam, The Netherlands. E-mail: a.vonk@vumc.nl

Received: Aug 192013 | Accepted after revision: Sept 152013

Support statement: A. Vonk Noordegraaf was supported by the Netherlands Organisation for Scientific Research-VIDI grant (project number 917.96.306).

Conflict of interest: Disclosures can be found alongside the online version of this article at err.ersjournals.com

Provenance: Submitted article, peer reviewed.

\title{
References
}

1 McLaughlin VV, Archer SL, Badesch DB, et al. ACCF/AHA 2009 expert consensus document on pulmonary hypertension a report of the American College of Cardiology Foundation Task Force on Expert Consensus Documents and the American Heart Association developed in collaboration with the American College of Chest Physicians, American Thoracic Society, Inc. and the Pulmonary Hypertension Association. J Am Coll Cardiol 2009; 53: $1573-1619$.

2 Raghu G. Idiopathic pulmonary fibrosis: guidelines for diagnosis and clinical management have advanced from consensus-based in 2000 to evidence-based in 2011. Eur Respir J 2011; 37: 743-746.

Wells AU. Managing diagnostic procedures in idiopathic pulmonary fibrosis. Eur Respir Rev 2013; 22: 158-162.

4 Cahill E, Costello CM, Rowan SC, et al. Gremlin plays a key role in the pathogenesis of pulmonary hypertension. Circulation 2012; 125: 920-930.

5 Costello CM, Howell K, Cahill E, et al. Lung-selective gene responses to alveolar hypoxia: potential role for the bone morphogenetic antagonist gremlin in pulmonary hypertension. Am J Physiol Lung Cell Mol Physiol 2008; 295: L272-L284.

6 Myllärniemi M, Lindholm P, Ryynänen MJ, et al. Gremlin-mediated decrease in bone morphogenetic protein signaling promotes pulmonary fibrosis. Am J Respir Crit Care Med 2008; 177: 321-329.

7 Koli K, Myllärniemi M, Vuorinen K, et al. Bone morphogenetic protein-4 inhibitor gremlin is overexpressed in idiopathic pulmonary fibrosis. Am J Pathol 2006; 169: 61-71.

8 Myllärniemi M, Vuorinen K, Pulkkinen V, et al. Gremlin localization and expression levels partially differentiate idiopathic interstitial pneumonia severity and subtype. J Pathol 2008; 214: 456-463.

9 Durrington HJ, Morrell NW. What we know and what we would like to know about genetics and pulmonary arterial hypertension. Int J Clin Pract Suppl 2009; 161: 11-16.

10 Costello CM, Cahill E, Martin F, et al. Role of gremlin in the lung: development and disease. Am J Respir Cell Mol Biol 2010; 42: 517-523.

\section{Pulse methylprednisolone in allergic bronchopulmonary aspergillosis exacerbations}

\author{
To the Editor:
}

Allergic bronchopulmonary aspergillosis (ABPA) is an immunological pulmonary disorder caused by hypersensitivity reactions to fungal antigens released by Aspergillus fumigatus [1]. Several aspects of the 
disease remain an enigma despite being described six decades ago by Hinson et al. [2]. The clinical presentation is that of poorly controlled asthma, mucus plugging and bronchiectasis [3], and the diagnosis of ABPA is made on a composite of clinico-radiological and immunological findings [4]. The primary management of ABPA involves the use of glucocorticoids as an anti-inflammatory agent. Azoles are used in patients with recurrent exacerbations, and act by decreasing the fungal burden in the airways, thereby preventing exacerbations [5]. The natural history of ABPA is characterised by repeated episodes of exacerbations requiring glucocorticoids for management [6-8]. Herein, we describe two patients in whom the disease activity remained uncontrolled despite treatment with oral corticosteroids and azoles. These patients were managed successfully with intravenous pulses of high-dose methylprednisolone. We also systematically review the literature on the use of high-dose intravenous methylprednisolone in ABPA.

A 48-year-old male with history of bronchial asthma since 20 years of age was diagnosed with ABPA 6 years previously: A. fumigatus specific IgE $102 \mathrm{kUA} \cdot \mathrm{L}^{-1}$; type I skin reaction against Aspergillus antigen; total serum IgE $1208 \mathrm{IU} \cdot \mathrm{mL}^{-1}$; central bronchiectasis; eosinophil count 620 cells $\mu \mathrm{L}^{-1}$; and A. fumigatus precipitins positive. During the course of the disease he had multiple exacerbations, which responded to oral steroids. The patient was also started on itraconazole $200 \mathrm{mg}$ twice daily (four courses, each of 6 months duration) for recurrent exacerbations. His last exacerbation was 8 months ago. Current therapy included prednisolone $15 \mathrm{mg}$ every other day along with inhaled bronchodilators and steroids. The patient presented with increasing shortness of breath, wheezing and cough for 1 week. A chest radiograph showed no evidence of any new infiltrates or atelectasis. Serum IgE levels were $11384.97 \mathrm{IU} \cdot \mathrm{mL}^{-1}$. He was started on oral prednisolone $50 \mathrm{mg}$ daily and itraconazole $200 \mathrm{mg}$ twice daily. However, the patient's general condition did not improve after 1 week of therapy and he was hospitalised with type II respiratory failure in the respiratory intensive care unit. The patient was managed with oxygen, intravenous antibiotics, nebulised bronchodilators and noninvasive ventilation. Sputum for bacterial cultures and acid-fast bacilli were negative. A chest radiograph was performed again and showed no new opacities. Due to a suboptimal response to oral steroids and itraconazole, he was administered pulse intravenous methylprednisolone at a dose of $1 \mathrm{~g}$ daily for 3 days to control his ABPA. Oral steroids were rapidly tapered over the next 8 weeks and the patient continued on prednisolone $15 \mathrm{mg}$ every other day, oral itraconazole $200 \mathrm{mg}$ twice daily, inhaled steroids and bronchodilators. On follow-up at 6 weeks, the patient was doing well and his IgE level was $2679.90 \mathrm{IU} \cdot \mathrm{mL}^{-1}$.

A 32-year-old female with known asthma for the past 20 years was diagnosed with ABPA 3 years ago: A. fumigatus specific IgE $53.3 \mathrm{kUA} \cdot \mathrm{L}^{-1}$; type I and III skin reaction against Aspergillus antigen; total IgE $4228 \mathrm{IU} \cdot \mathrm{mL}^{-1}$; central bronchiectasis and high-attenuation mucus; eosinophil count $240 \mathrm{cells} \cdot \mu \mathrm{L}^{-1}$; and A. fumigatus precipitins positive. She was initiated on oral prednisolone $30 \mathrm{mg}$ daily with which there was clinical and radiological response and her serum IgE levels fell to a nadir of $2200 \mathrm{IU} \cdot \mathrm{mL}^{-1}$. During the subsequent 2 years she had two episodes of exacerbation of asthma, which were managed with oral steroids for 5 days each. In the current episode, the patient presented with history of worsening dyspnoea. Chest radiographs showed no new abnormality but her IgE level rose to $4149 \mathrm{IU} \cdot \mathrm{mL}^{-1}$. She was started on itraconazole (200 mg twice daily) and oral prednisolone $40 \mathrm{mg}$ daily. There was no response to therapy after 1 week and she was hospitalised. She was hypoxaemic at presentation and was treated with oxygen, intravenous antibiotics and nebulised bronchodilators. During her hospital stay, sputum cultures and smears for acid-fast bacilli were negative; compression ultrasound for deep vein thrombosis and D-dimers were also negative. To control her ABPA, the patient received intravenous methylprednisolone $1 \mathrm{~g}$ daily for 3 days. This was followed by an improvement in the patient's symptoms and on discharge after 10 days, her room-air oxygen saturation rose to $96 \%$. Oral steroids were subsequently tapered over the next 2 months to $15 \mathrm{mg}$ every other day. Treatment with oral itraconazole $200 \mathrm{mg}$ twice daily, inhaled steroids and bronchodilators were continued. Her serum IgE level 4 weeks after pulse therapy was $1220 \mathrm{IU} \cdot \mathrm{mL}^{-1}$ and reached a nadir of $784 \mathrm{IU} \cdot \mathrm{mL}^{-1} 3$ months after receiving pulse methylprednisolone.

Escalating the dose of oral steroids constitutes the backbone of treating ABPA exacerbations; however, the management of an occasional ABPA patient may prove challenging. Both the index cases failed to respond to high doses of oral steroids and itraconazole and were managed with intravenous methylprednisolone pulse therapy. A systematic review of the PubMed and EMBASE databases using the search terms: "allergic bronchopulmonary aspergillosis" OR "abpa" OR "abpm" OR "allergic bronchopulmonary mycosis" yielded four reports (39 cases) on the use of high doses of intravenous methylprednisolone in the management of ABPA [9-12]. All the reports were in patients with ABPA complicating cystic fibrosis, and involved both adult and paediatric patients (table 1). Three reports used pulse methylprednisolone 10-20 mg $\mathrm{kg}^{-1}$ as a steroid sparing agent for three consecutive days every month $[9,10,12]$. One report involves the use of high-dose methylprednisolone in a life-threatening ABPA exacerbation unresponsive to oral steroid, which is similar to our cases [11]. Our cases are the first report on the use of pulse methylprednisolone in the management of ABPA exacerbations in adult asthmatic patients. 
TABLE 1 Studies describing the use of high-dose intravenous methylprednisolone in allergic bronchopulmonary aspergillosis

\begin{tabular}{|c|c|c|c|c|c|c|c|c|c|}
\hline $\begin{array}{l}\text { Fist author } \\
\text { [ref.] }\end{array}$ & Patients & $\begin{array}{l}\text { Age } \\
\text { years }\end{array}$ & $M / F$ & $\begin{array}{l}\text { Risk } \\
\text { factor }\end{array}$ & $\begin{array}{l}\text { Mean serum } \\
\lg E \mathrm{IU} \cdot \mathrm{mL}^{-1}\end{array}$ & $\begin{array}{l}\text { Methylprednisol- } \\
\text { one dose }\end{array}$ & $\begin{array}{l}\text { Steroid } \\
\text { duration }\end{array}$ & Outcomes & Side-effects \\
\hline Thомson [9] & 4 & $\begin{array}{c}6.075 \\
(1.7-8.2)\end{array}$ & $3 / 1$ & CF & 2950.5 & $\begin{array}{c}20 \mathrm{mg} \cdot \mathrm{kg}^{-1} \text { every } \\
4 \text { weeks }\end{array}$ & 4 years & $\begin{array}{l}3 \text { out of } 4 \text { patients } \\
\text { had clinical } \\
\text { stabilisation }\end{array}$ & $\begin{array}{l}\text { Hypertension and } \\
\text { hyperglycaemia in } \\
\text { one patient each }\end{array}$ \\
\hline $\begin{array}{l}\text { CoHEN- } \\
\text { CymberKnOH } \\
\text { [10] }\end{array}$ & 9 & $\begin{array}{c}17.1 \\
(7-36)\end{array}$ & $4 / 5$ & CF & 542 & $\begin{array}{c}10-15 \mathrm{mg} \cdot \mathrm{kg}^{-1} \\
\text { (max } 1 \mathrm{~g} \text { ) every } \\
4 \text { weeks }\end{array}$ & $\begin{array}{l}\text { 6-10 } \\
\text { months }\end{array}$ & $\begin{array}{l}\text { Significant } \\
\text { improvement in } \\
\text { FEV1 and } \\
\text { decreased IgE in } \\
\text { all cases }\end{array}$ & $\begin{array}{l}\text { Weight gain and } \\
\text { psychiatric } \\
\text { disorder in one } \\
\text { patient each }\end{array}$ \\
\hline Thomas [11] & 1 & 11 & $1 / 0$ & $\mathrm{CF}$ & 9178 & $\begin{array}{c}20 \mathrm{mg} \cdot \mathrm{kg}^{-1} \text { for } \\
3 \text { days followed by } \\
10 \mathrm{mg} \cdot \mathrm{kg}^{-1} \text { for } \\
3 \text { days }\end{array}$ & 6 days & $\begin{array}{c}\text { Clinical } \\
\text { stabilisation }\end{array}$ & \\
\hline Skov [12] & 25 & $\begin{array}{c}19.9 \\
(10-34)\end{array}$ & $16 / 9$ & $\mathrm{CF}$ & NA & $15 \mathrm{mg} \cdot \mathrm{kg}^{-1}$ & $\begin{array}{c}3-7 \\
\text { months }\end{array}$ & $\begin{array}{l}\text { Clinical } \\
\text { stabilisation; } \\
\text { reduction in the } \\
\text { number of } \\
\text { exacerbations }\end{array}$ & $\begin{array}{c}\text { Minimal } \\
\text { side-effects }\end{array}$ \\
\hline
\end{tabular}

Data are presented as $\mathrm{n}$ or mean (range), unless otherwise stated. M: males; F: females; CF: cystic fibrosis; NA: not available; FEV1: forced expiratory volume in $1 \mathrm{~s}$.

ABPA is caused by abnormal immune responses to fungal antigens with preferential activation of T-helper type 2 responses and subsequent release of pro-inflammatory cytokines [13]. ABPA exacerbations probably reflect heightened immune activity triggered by increased fungal colonisation [1]. The differential diagnosis of ABPA exacerbation includes exacerbation of asthma, pulmonary embolism and pneumonia. However, ABPA exacerbations are characterised by clinico-radiological worsening associated with elevation of serum IgE levels $50-100 \%$ of the baseline value [4]. The rationale behind the use of steroids in ABPA exacerbations is their ability to relieve airway obstruction, decrease sputum production and hasten resolution of pulmonary infiltrates due to their anti-inflammatory effects (inhibition of phospholipase A2 activity and arachidonic acid metabolism, decrease in inflammatory cell chemotaxis, cell adhesion and tissue infiltration, and diminished production of inflammatory cytokines) [14]. We have previously shown that the presence of severe bronchiectasis and high-attenuation mucus is associated with recurrent relapses [15-17]. Both our patients had severe bronchiectasis while one patient had high-attenuation mucus. In addition, due to the severity of their underlying disease, both patients had been on long-term oral steroids. Long-term steroid use is associated with downregulation of steroid receptors and, hence, creation of a steroid resistance state [18]. Use of high doses of methylprednisolone may overcome this effect by its non-genomic physicochemical actions, which are independent of the steroid receptors [19].

The use of methylprednisolone in acute exacerbations of ABPA has been previously described in a single case of an 11-year-old child with cystic fibrosis, where the exacerbation was unresponsive to oral steroids and pulsed doses of methylprednisolone led to clinical stabilisation and better control of ABPA [11]. Our patients were even sicker, and were unresponsive to both prednisolone and itraconazole. Use of pulsed doses of methylprednisolone led to clinical stabilisation in both cases, and we were able to reduce the dose of oral prednisolone within 4-8 weeks. Intravenous monthly pulses of methylprednisolone have also been used as a steroid-sparing agent to prevent various side-effects like hyperglycaemia, hypertension and osteoporosis. In fact, in three published studies none of the patients gained weight or developed cushingoid habitus in studies employing monthly pulses of methylprednisolone, and there was no suppression of hypothalamic-pituitary axis $[9,10,12]$. In acute exacerbations of ABPA, pulse methylprednisolone should currently be considered in those refractory to oral prednisolone and itraconazole or in those who develop acute respiratory failure due to acute exacerbation. Therapeutic bronchoscopy should be considered before pulse methylprednisolone in those with large airway collapse, [20]. The administration of high doses of methylprednisolone may be rarely associated with complications like cardiac arrhythmias and circulatory collapse usually following rapid administration [19]. Hence, the infusion should be given gradually over $2 \mathrm{~h}$, and the patients should be closely observed during the pulse therapy. 
In conclusion, pulsed doses of intravenous methylprednisolone are safe and effective, which can be used in managing ABPA exacerbations unresponsive to conventional therapy with oral steroids and azoles.

\section{0} @ERSpublications

Methylprednisolone pulse therapy is safe and effective for ABPA exacerbations unresponsive to conventional therapy http://ow.ly/q89Sy

Inderpaul Singh Sehgal and Ritesh Agarwal

Dept of Pulmonary Medicine, Postgraduate Institute of Medical Education and Research, Chandigarh, India.

Correspondence: R. Agarwal, Dept of Pulmonary Medicine, Postgraduate Institute of Medical Education and Research, Sector 12, Chandigarh, CH-160012, India. E-mail: riteshpgi@gmail.com

Received: June 242013 | Accepted after revision: July 162013

Conflict of interest: None declared.

Provenance: Submitted article, peer reviewed.

\section{References}

Agarwal R. Allergic bronchopulmonary aspergillosis. Chest 2009; 135: 805-826.

2 Hinson KF, Moon AJ, Plummer NS. Broncho-pulmonary aspergillosis; a review and a report of eight new cases. Thorax 1952; 7: 317-333.

3 Agarwal R, Chakrabarti A. Clinical manifestations and natural history of allergic bronchopulmonary aspergillosis. In: Pasqualotto AC, ed. Aspergillosis: From Diagnosis to Prevention. New York, Springer, 2010; pp. 707-724.

4 Agarwal R, Chakrabarti A, Shah A, et al. Allergic bronchopulmonary aspergillosis: review of literature and proposal of new diagnostic and classification criteria. Clin Exp Allergy 2013; 43: 850-873.

5 Agarwal R. What is the current place of azoles in allergic bronchopulmonary aspergillosis and severe asthma with fungal sensitization. Expert Rev Respir Med 2012; 6: 363-371.

6 Lee TM, Greenberger PA, Patterson R, et al. Stage V (fibrotic) allergic bronchopulmonary aspergillosis. A review of 17 cases followed from diagnosis. Arch Intern Med 1987; 147: 319-323.

7 Wang JL, Patterson R, Roberts M, et al. The management of allergic bronchopulmonary aspergillosis. Am Rev Respir Dis 1979; 120: 87-92.

8 Rosenberg M, Patterson R, Roberts M, et al. The assessment of immunologic and clinical changes occurring during corticosteroid therapy for allergic bronchopulmonary aspergillosis. Am J Med 1978; 64: 599-606.

9 Thomson JM, Wesley A, Byrnes CA, et al. Pulse intravenous methylprednisolone for resistant allergic bronchopulmonary aspergillosis in cystic fibrosis. Pediatr Pulmonol 2006; 41: 164-170.

10 Cohen-Cymberknoh M, Blau H, Shoseyov D, et al. Intravenous monthly pulse methylprednisolone treatment for ABPA in patients with cystic fibrosis. J Cyst Fibros 2009; 8: 253-257.

11 Thomas MF. Life-threatening allergic bronchopulmonary aspergillosis treated with methylprednisolone and antiIgE monoclonal antibody. J R Soc Med 2009; 102: Suppl. 1, 49-53.

12 Skov M. High-dose IV-pulse methylprednisolone (HDIVPM) successful treatment of allergic bronchopulmonary aspergillosis (ABPA). Pediatr Pulmonol 2010; 45: 365.

13 Agarwal R. Allergic bronchopulmonary aspergillosis: lessons learnt from genetics. Indian J Chest Dis Allied Sci 2011; 53: $137-140$.

14 Webster JC, Oakley RH, Jewell CM, et al. Proinflammatory cytokines regulate human glucocorticoid receptor gene expression and lead to the accumulation of the dominant negative beta isoform: a mechanism for the generation of glucocorticoid resistance. Proc Natl Acad Sci USA 2001; 98: 6865-6870.

15 Agarwal R, Gupta D, Aggarwal AN, et al. Clinical significance of hyperattenuating mucoid impaction in allergic bronchopulmonary aspergillosis: an analysis of 155 patients. Chest 2007; 132: 1183-1190.

16 Agarwal R, Khan A, Gupta D, et al. An alternate method of classifying allergic bronchopulmonary aspergillosis based on high-attenuation mucus. PLoS One 2010; 5: e15346.

17 Agarwal R, Gupta D, Aggarwal AN, et al. Clinical significance of decline in serum IgE levels in allergic bronchopulmonary aspergillosis. Respir Med 2010; 104: 204-210.

18 Barnes PJ, Adcock IM. Glucocorticoid resistance in inflammatory diseases. Lancet 2009; 373: 1905-1917.

19 Sinha A, Bagga A. Pulse steroid therapy. Indian J Pediatr 2008; 75: 1057-1066.

20 Agarwal R, Aggarwal AN, Gupta N, et al. A rare cause of acute respiratory failure-allergic bronchopulmonary aspergillosis. Mycoses 2011; 54: e223-e227. 